\title{
PASSENGER PREFERENCES IN RAIL TRANSPORT
}

\section{GRAŻYNA ROSA}

University of Szczecin, Faculty of Management and Economics of Services, POLAND

email: grazyna.rosa@wzieu.pl

\author{
\begin{tabular}{l|l} 
RECEIVED & 6 November 2018
\end{tabular} \\ ACCEPTED 3 December 2018 \\ JEL \\ CLASSIFICATION \\ D12, L91, L92, R41 \\ KEYWORDS rail transport, passenger transport, communication behaviour
}

ABSTRACT The article presents the preferences of rail transport travellers based on the results of secondary and primary research (hierarchy of importance of the characteristics of passenger transport services and assessment of their implementation) in comparison to changes in the environment of transport companies, which are also an opportunity to develop passenger rail transport. The aim of this article is to indicate the most significant characteristics of passenger rail transport services for service recipients, as well as evaluate the implementation of these characteristics by entities offering passenger rail transport services in Poland, and at the same time determine the gap that occurs in the assessments of these perspectives by travellers. In order to achieve the objective, the desk research method, which takes into account the available literature and results of secondary research published by Urząd Transportu Kolejowego (the Office of Rail Transport) and the Central Statistical Office (GUS) that open new possibilities for carriers in the scope of analysing and adapting to the expectations of service recipients, as well as the survey method using the questionnaire in primary research, were applied. Finally, passenger rail transport in regions and agglomerations in Poland was chosen as a research area.

\section{Introduction}

The subject of passenger transport, including rail transport, is discussed in the literature by a relatively small number of authors (Bąkowski, Szewczuk, 2000; Engelhardt, 2007; Paprocki, 1996; Rosa, 2013; Tomanek, 2002; Wyszomirski, 1994, 1998). The passenger transport market is very dynamic and undergoes constant transformations that result mainly from changes taking place in the transport environment. The phenomenon 
of congestion, high volume of traffic on the roads, and, as a result, slower travel time in the case of individual and inland mass transport (buses), as well as a significant improvement of railway infrastructure, purchases of modern rolling stock that enables effective use of time during the journey, gradual introduction of an integrated rail ticket, the possibility of purchasing and presenting a ticket in electronic form, additionally affect the competitiveness of railway undertakings against road transport, mainly private.

The number of passengers choosing rail transport in Poland reached the level of 280.3 million in 2015, which represented an increase by $4.2 \%$, when compared to 2014 (269.1 million). The year 2016 brought a further increase of $4.3 \%$ and ended with the result of 292.5 million passengers, which shows that an average Polish citizen travelled by rail only several times in $2016^{1}$ (Wykorzystanie..., 2017, p. 12).

The average density of normal gauge railway lines in Poland is $6 \mathrm{~km}$ per $100 \mathrm{~km}^{2}$ (below the average - in the eastern part of the country, above the average - in the western part, which is mainly due to historical reasons). The highest density is recorded in Śląskie voivodeship ( $16 \mathrm{~km}$ of lines per $100 \mathrm{~km}^{2}$ ), where the usage rate is 4.3 trips a year. A rate much lower than the average value in this area may result from the well-developed road network, which facilitates transport between adjacent cities in the Upper Silesian urban area. Another problem concerns the poor condition of railway infrastructure, problems with capacity and low commercial speed of trains. Infrastructure and the location of stops should allow their usage by the largest possible flows of travellers, as well as adaptation to the needs of the disabled. However, it should be remembered that even a dense, but not adapted infrastructure, will not encourage passengers to use rail transport. In places where it is difficult to adjust the railway infrastructure, intermodality should be chosen (e.g. construction of park and ride car parks, city bikes, adjustment of the train timetable to city buses or trams). The most important issues railway undertakings should concentrate on are:

- effective use of the increasingly modern rolling stock and better infrastructure,

- a well-designed timetable (appropriately adjusted departure times, cyclicality of the timetable and frequency of running of trains),

- an appropriate level of service,

- an offer of an integrated ticket for all means of transport.

The aim of this article is to indicate the most significant characteristics of passenger rail transport services for service recipients, as well as evaluate the implementation of these characteristics by entities offering passenger rail transport services in Poland, and at the same time determine the gap that occurs in the assessments of these perspectives by travellers. In order to achieve the objective, the method of critical analysis of available results of secondary research and the questionnaire used in primary research were applied.

\section{Poles' communication hehaviour}

In the 1980s, rail transport served much more passengers, while the passenger car was a considerably less available means of transport. The situation began to change in the $90 \mathrm{~s}$, when the railway felt the impact

${ }^{1}$ In an attempt to compare the situation on the railways in individual voivodeships, UTK introduced the "usage rate". It is calculated as the quotient of the number of passenger train journeys (presented in the statistics as the number of passengers) and the number of inhabitants of a given area. In Poland, the rate is at the level of 7.6 trips a year, which means that statistically, every Pole rode almost eight times by train in 2016. The usage rate is equal to the quotient of the number of passengers in Poland and the number of inhabitants of Poland. The number of passengers in 2016 was taken into account -292.5 million and the number of inhabitants according to the Central Statistical Office (GUS) data from January $2016-38.4$ million. The usage rate calculated in this way is 7.6 (Wykorzystanie..., 2017, p. 2). 
of underinvestment. Contemporary transport market (covering both passenger and freight transport services) is a customer market. The oversupply of services in the passenger transport market is caused by the development of individual motorisation, which meets most of the demand for transport services on the market.

Table 1 presents the share of two means of transport: passenger cars and railways in trips of a statistical inhabitant of each voivodeship. For comparison, it was assumed that the total number of trips by both rail and passenger cars is $100 \%$, due to direct competition between these modes of transport. ${ }^{2}$

Table 1. The share of rail passenger transport and passenger cars per statistical inhabitant of the voivodeship above 16 years of age in 2015

\begin{tabular}{lcccc}
\hline & \multicolumn{2}{c}{$\begin{array}{c}\text { Number of passengers in millions } \\
\text { (over the age of 16) }\end{array}$} & Share (\%) \\
\cline { 2 - 5 } Voivodeship & rail & car & rail & car \\
\hline Pomorskie & 45.1 & 383.8 & 11 & 89 \\
Mazowieckie & 90.4 & 879.8 & 9 & 91 \\
Wielkopolskie & 22.0 & 750.2 & 3 & 97 \\
Dolnoślaskie & 15.9 & 598.9 & 3 & 97 \\
Zachodniopomorskie & 7.7 & 250.6 & 3 & 97 \\
Opolskie & 4.4 & 205.7 & 2 & 98 \\
Małopolskie & 9.0 & 567.4 & 2 & 98 \\
Śląskie & 17.1 & 881.2 & 2 & 98 \\
Łódzkie & 7.9 & 461.1 & 2 & 98 \\
Kujawsko-pomorskie & 6.3 & 417.7 & 1 & 99 \\
Lubuskie & 2.6 & 204.2 & 1 & 99 \\
Warmińsko-mazurskie & 3.8 & 257.0 & 1 & 99 \\
Lubelskie & 4.7 & 375.5 & 1 & 99 \\
Świętokrzyskie & 2.0 & 224.3 & 1 & 99 \\
Podkarpackie & 2.6 & 414.1 & 1 & 99 \\
Podlaskie & 1.3 & 215.6 & 1 & 99 \\
\hline Poland & 242.7 & $7,087.10$ & 3 & 97 \\
\hline
\end{tabular}

Source: Wykorzystanie... (2017), p. 8; based on UTK and GUS data.

The share of rail transport in passenger transport is small, around $3 \%$, with the remaining $97 \%$ consisting of road transport.

The communication behaviours of the service recipients can be characterized by such categories as: preferences and reasons for using particular means of transport, the manner and scope of their use, purpose of travel, average time, distance and frequency of travel. The research results presented hereinafter in such a scale

${ }^{2}$ Data concerning individual transport by passenger cars come from the research work of the Central Statistical Office (GUS), titled "Badanie pilotażowe zachowań komunikacyjnych ludności w Polsce". The GUS survey involved people aged 16 and over. In order for the UTK data to be comparable with the data of the Central Statistical Office, the total number of passengers under 16 years of age was deducted from the total number of passengers using railway services. The estimation was made on the basis of information obtained from rail undertakings concerning the percentage of passengers at their subsidies using discounts for children and adolescents no older than 24 , in the period starting from compulsory annual pre-school preparation to graduating from junior high school, post primary or post-secondary school - public or private with public school entitlements, considering this group to be the most comparable to the group of passengers under 16 years. In the case of SKM Warszawa and WKD, which did not have information about passengers under 16, the value of the percentage accepted by Koleje Mazowieckie was used (Wykorzystanie..., 2017, p. 8). 
and scope are pioneering in the transport services market as well as open new possibilities for carriers in the scope of analysing the expectations of service recipients and adapting to them.

The pilot survey ${ }^{3}$ concerning transport behaviour of the population included 13,551 households with 30,886 people aged 16 and more. 25,591 respondents (45.3\% of men and $54.7 \%$ of women) took part in the appropriate survey. The largest age group interviewed were people aged 65 and more (over 20\%), 35-44 years (about 17\%), 45-54 (about 16\%) and 25-34 (over 15\%) (Centrum Badań i Edukacji Statystycznej GUS, 2015, pp. 11-24, 40).

Passenger cars are used to a large extent when travelling to work and school (university). Based on the conducted interviews, it was established that the share of people travelling to work and school (university) in the total number of these respondents exceeds $55 \%$. Nearly $64 \%$ of people commute by car (about $56 \%$ as drivers and over $8 \%$ as passengers). The highest percentage of commuters was recorded in Podkarpackie (nearly $75 \%$ ), Świętokrzyskie and Lubelskie (70\% each) voivodeships, whereas the lowest in Mazowieckie (over 57\%) and Pomorskie voivodships (over $58 \%$ ). More than $20 \%$ of students covered by the survey declare that they travel to school (university) by passenger car (over $11 \%$ as drivers and nearly $9 \%$ as passengers) (Centrum Badań i Edukacji Statystycznej GUS, 2015, p. 36).

The main reasons indicated by the respondents for choosing a passenger car when travelling to work or school instead of public transport are too distant public transport stop/station (about 39\%) and the lack of appropriate connections in the public transport timetable (over 30\%). Another important reason is the unacceptable travel time by public transport (over 16\%). $10 \%$ of respondents have to commute to the nearest stop/station. Slightly over $3 \%$ of respondents indicate the comfort of travel as the reason for preferring this way of traveling, and $1 \%$ use a company car when commuting (Centrum Badań i Edukacji Statystycznej GUS, 2015, p. 37).

Mobility of people aged 16 and more in individual voivodships is diverse. The largest occurs in the voivodeship of Dolnośląskie (447 trips), Mazowieckie (444) and Śląskie (443), whereas the smallest in Zachodniopomorskie (347), Warmińsko-mazurskie and Świętokrzyskie (392 trips) as well as Podlaskie voivodeships (Centrum Badań i Edukacji Statystycznej GUS, 2015, p. 38). The highest mobility (without taking back trips) is shown by people traveling to work. Over 100 of these trips within a year are made by one person from the population covered by the study. The reasons for increased mobility of people is related to shopping (43 trips) and meeting personal needs (22 trips), travelling to schools (17 trips), as well as spending free time (15 trips).

The public mass transit services are used on average by $20 \%$ of passengers (people), $14.6 \%$ of which use public transport (including trams and trolleybuses - approx. 3\%), $4.2 \%$ bus transport out of town, and 1.2\% - rail transport. Public transport is the most popular in Pomorskie (27.6\%), Mazowieckie (27.3\%) voivoideships, and the least in Lubuskie (11.6\%), Opolskie (12.3\%) and Wielkopolskie (12.9\%) (Centrum Badań i Edukacji Statystycznej GUS, 2015, p. 41).

The average distance travelled depends on the means of transport used. Car journeys are made on the average distance of $17.9 \mathrm{~km}$, by motorcycle (scooter) and moped - $11.8 \mathrm{~km}$ in total, by public transport - on a distance of $9.5 \mathrm{~km}$, by bus transport out of town $-26.6 \mathrm{~km}$, and by rail transport $54.4 \mathrm{~km}$ on average (passenger trains - 37.2 km, and fast trains - 151.0, km) (Centrum Badań i Edukacji Statystycznej GUS, 2015, p. 43).

The average travel time varies depending on the destination. For all types of trips, in total, it is 24 minutes on the national scale. Commuting takes about 24 minutes, whereas travelling to school (university) - 30 minutes.

\footnotetext{
${ }^{3}$ Developed on the basis of: Centrum Badań i Edukacji Statystycznej GUS (2015).
} 
The average travel time associated with spending free time is about 33 minutes, and for shopping - about 15 minutes. Travels for personal needs take on average 21 minutes, whereas to return home - 24 minutes. Moreover, the average travel time depends on the mode of transport. In all types of journeys for pedestrians, it is about 15 minutes on average, 22 minutes for bicycle, 21 minutes by car, 25 minutes by public transport and 32 minutes by public bus transport out of town. A journey by train lasts on average 53 minutes.

The people who cover the most kilometres when commuting are residents of Kujawsko-pomorskie (the average distance of $14.8 \mathrm{~km})$, Wielkopolskie $(14.5 \mathrm{~km})$, Pomorskie $(14.2 \mathrm{~km})$ and Lubelskie $(14.0 \mathrm{~km})$ voivodeships. The shortest commuting is made by the residents of Podlaskie $(9.7 \mathrm{~km})$ and Warmińsko-mazurskie $(10.0 \mathrm{~km})$ voivodeships. The longest journey to school (university) are made by people from Lubelskie $(19.1 \mathrm{~km})$, Wielkopolskie $(14.0 \mathrm{~km})$ and Lubuskie $(13.6 \mathrm{~km})$ voivodeships, whereas the shortest from Dolnośląskie $(9.6 \mathrm{~km})$ and Warmińskomazurskie voivodeships $(9.9 \mathrm{~km})$. As far as shopping purposes are concerned, the residents of Zachodniopomorskie $(10.0 \mathrm{~km})$ and Warmińsko-mazurskie $(9.2 \mathrm{~km})$ voivodeships go to the furthest places, whereas the residents of Ślaskie $(5.4 \mathrm{~km})$, Małopolskie $(6.1 \mathrm{~km})$, Dolnoślaskie and Mazowieckie voivodeships travel to the nearest places $(6.5 \mathrm{~km})$. The furthest travels to spend free time are made by people from Małopolskie $(36.7 \mathrm{~km})$, Zachodniopomorskie $(35.6 \mathrm{~km})$ and Mazowieckie $(34.5 \mathrm{~km})$ voivodships. The residents of Podkarpackie, Kujawsko-Pomorskie, Śląskie and Wielkopolskie voivodships cover the shortest distances (the average distance respectively: $19.2 \mathrm{~km}, 22.1 \mathrm{~km}$, $22.8 \mathrm{~km}$ and $22.9 \mathrm{~km})$.

The predominant number of trips in the country takes place using passenger cars. Their share in general transport in Poland amounts to $54.5 \%$, and in the total number of passenger kilometres (i.e. taking into account the distance) is even larger $-68.5 \%$. The total mileage of passenger cars in all types of journeys made by people from the surveyed population amounts to approximately 113.6 billion $\mathrm{km}$ per year, including over $75 \%$ of car journeys taking place during weekdays. The most common distances travelled by car are of $11-20 \mathrm{~km}(23.1 \%)$ and $21-30 \mathrm{~km}$ (15.8\%) (Centrum Badań i Edukacji Statystycznej GUS, 2015, p. 45).

Most commonly, passenger cars are used to commute, as well as go shopping, spend free time and meet personal needs. The mileage of cars in achieving these goals amounts to $27.2 \%$ (commuting to work), $5.2 \%$ (shopping), $4.6 \%$ (spending free time), $4.2 \%$ (personal needs) of general passenger car mileage. Mileage concerning trips home is $47.7 \%$.

The presented research results can be an important cognitive material for railway undertakings, carrying out transport services in regions (voivodeships) and agglomerations, which will encourage them to conduct further indepth research on the possibility of adapting their offer to individual transport users, who spend more and more rush hours in 'traffic jams' and incur parking costs in city centres.

\section{Passenger preferences and evaluation of railway sepvices performance - results of primary research}

The research was carried out from October 2017 to March 2018 on a sample of 350 people from all over Poland, chosen deliberately in terms of age, in order to obtain a homogeneous sample of "young adults" aged 18-29. A questionnaire was used to carry out the survey. While developing the completed questionnaires, it was found that 19 of them are incomplete, and thus 331 people were accepted for further development and assessment. The aim of the research was to identify the key characteristics of passenger transport services that are relevant to service recipients, as well assess the implementation of these characteristics by entities providing rail transport services in Poland. 
Table 2 presents the distribution of responses to the question regarding the importance of the characteristics of passenger rail transport services.

Table 2. The rank of importance of the characteristics of passenger rail transport services (\%)

\begin{tabular}{|c|c|c|c|c|}
\hline The rank of importance/the characteristics of passenger rail transport services & $\begin{array}{c}\text { Very } \\
\text { important }\end{array}$ & Important & $\begin{array}{c}\text { Less } \\
\text { important }\end{array}$ & Not important \\
\hline The manner of presenting the offer (leaflets, brochures, information, promotions) & 13 & 33 & 35 & 20 \\
\hline Ticket prices & 66 & 26 & 4 & 3 \\
\hline Price promotions & 58 & 29 & 9 & 4 \\
\hline Direct communication with personnel & 35 & 41 & 18 & 7 \\
\hline Safety in means of transport & 69 & 22 & 4 & 4 \\
\hline Possibility to track information on social media & 19 & 29 & 37 & 15 \\
\hline Equipment of means of transport & 45 & 41 & 9 & 5 \\
\hline Number of transfers & 69 & 21 & 7 & 3 \\
\hline Travel time & 69 & 22 & 6 & 3 \\
\hline Convenient connection times & 75 & 19 & 4 & 3 \\
\hline Number of connections & 69 & 24 & 5 & 3 \\
\hline Well-known brand & 17 & 23 & 40 & 21 \\
\hline Punctuality & 73 & 18 & 6 & 3 \\
\hline Quality of rendered services & 63 & 29 & 6 & 2 \\
\hline Employee competencies & 42 & 43 & 11 & 3 \\
\hline A guarantee of a refund in case of delays & 42 & 37 & 17 & 4 \\
\hline Providing additional services such as Wi-Fi & 32 & 36 & 26 & 7 \\
\hline Possibility to check connections on the Internet & 70 & 20 & 7 & 3 \\
\hline The possibility of having a ticket in electronic form & 54 & 28 & 12 & 6 \\
\hline The possibility of buying a ticket via the Internet & 61 & 24 & 11 & 3 \\
\hline Purchase of a ticket using mobile devices & 56 & 27 & 13 & 5 \\
\hline The possibility of buying a ticket once inside the vehicle & 57 & 27 & 11 & 4 \\
\hline Displaying/informing about the next station/stop & 53 & 33 & 10 & 4 \\
\hline Tracking the route and location of the vehicle while traveling through applications & 43 & 27 & 23 & 7 \\
\hline
\end{tabular}

Source: own research results, $\mathrm{N}=331$.

The research shows that the most important characteristics of rail passenger transport services (responses: very important and important) for young buyers (service recipients) are:

- convenient connection hours (the most important characteristics),

- ticket price,

- safety in means of transport,

- duration of the journey,

- number of transfers,

- number of connections,

- punctuality,

- the quality of services provided,

- the ability to check connections on the Internet. 
Completely of no importance for the respondents were: the manner of presenting the offer (leaflets, brochures, information, promotions), the ability to track information on social media, and well-known brand.

Table 3 presents the distribution of responses to the question regarding the assessment of the implementation of the characteristics of passenger rail transport services.

Table 3. Assessment of the implementation of the characteristics of passenger rail transport services (\%)

\begin{tabular}{|c|c|c|c|c|}
\hline $\begin{array}{l}\text { Assessment of the implementation of the characteristics } \\
\text { of passenger rail transport services }\end{array}$ & Very good & Good & Bad & Very bad \\
\hline The manner of presenting the offer (leaflets, brochures, information, promotions) & 17 & 57 & 20 & 6 \\
\hline Prices & 21 & 59 & 19 & 1 \\
\hline Price promotions & 21 & 38 & 35 & 6 \\
\hline Direct communication with personnel & 19 & 55 & 21 & 4 \\
\hline Safety in means of transport & 32 & 52 & 15 & 1 \\
\hline Possibility to track information on social media & 14 & 41 & 36 & 9 \\
\hline Equipment of means of transport & 16 & 51 & 27 & 6 \\
\hline Number of transfers & 19 & 54 & 23 & 4 \\
\hline Travel time & 17 & 46 & 28 & 9 \\
\hline Convenient connection times & 17 & 46 & 31 & 6 \\
\hline Number of connections & 17 & 45 & 31 & 7 \\
\hline Well-known brand & 19 & 60 & 15 & 6 \\
\hline Punctuality & 14 & 37 & 33 & 16 \\
\hline Quality of rendered services & 16 & 58 & 20 & 6 \\
\hline Employee competencies & 18 & 64 & 16 & 2 \\
\hline A guarantee of a refund in case of delays & 12 & 29 & 38 & 21 \\
\hline Providing additional services such as $\mathrm{Wi}-\mathrm{Fi}$ & 15 & 34 & 40 & 11 \\
\hline Possibility to check connections on the Internet & 51 & 40 & 7 & 2 \\
\hline The possibility of having a ticket in electronic form & 50 & 40 & 8 & 2 \\
\hline Possibility of buying a ticket via the Internet & 52 & 39 & 8 & 1 \\
\hline Purchase of a ticket using mobile devices & 43 & 44 & 11 & 2 \\
\hline The possibility of buying a ticket once inside the vehicle & 31 & 44 & 19 & 6 \\
\hline Displaying/informing about the next station/stop & 33 & 50 & 13 & 4 \\
\hline Tracking the route and location of the vehicle while traveling through applications & 21 & 38 & 30 & 11 \\
\hline
\end{tabular}

Source: own research results, $N=331$.

The research shows that the best-performed characteristics of passenger rail transport services (responses: very good and well) according to young buyers (service recipients) are:

- safety in means of transport,

- the possibility of having a ticket in electronic form,

- employee competencies,

- possibility to check connections on the Internet,

- purchase of a ticket using mobile devices,

- displaying/informing about the next station/stop.

However, the worst implemented characteristics of passenger rail transport services (answers: bad and very bad) according to young buyers (service buyers) are: punctuality, tracking of the route and the place of the vehicle 
through applications during the journey, a guarantee of a refund in case of delays, provision of additional services such as wi-fi, travel time, convenient connection times (the most important characteristics), number of connections.

\section{Conclusions}

When taking into consideration the small share of rail transport in passenger transport, reasons and purposes of using passenger cars should be analysed very carefully. Cars are used primarily for commuting, as well as shopping and spending free time. The main reasons for choosing a passenger car when travelling to work or school instead of public transport indicated by the respondents (in the presented results of secondary research) are considerable distance to the nearest public transport stop/station, the lack of appropriate connections in the public transport timetable as well as unacceptable travel time by public transport.

This was confirmed by the results of the primary research, which showed that for young buyers (service recipients), the most important characteristics are, first and foremost, convenient connection hours (the most important characteristics). Almost equally important responses included the price of tickets, safety in means of transport, travel time, the number of transfers, the number of connections, punctuality, quality of services provided and the possibility to check connections on the Internet. Furthermore, most of the important characteristics are implemented at low level by railway undertakings. This is a very important finding, which at the same time indicates the direction of changes in the implementation of passenger rail transport services.

The market-oriented approach of railway undertakings is also important, as among the priorities of the action reorientation they mention: effective use of the increasingly modern rolling stock and infrastructure, a well-thought-out timetable structure and offering an appropriate higher level of service, which mostly meets the expectations of travellers.

\section{References}

Bąkowski, W., Szewczuk, A. (eds.) (2000). Strategie konkurowania na rynku transportowym. Ogólnopolska Konferencja Naukowa "Ektra 2000". Szczecin: Fundacja na rzecz Uniwersytetu Szczecińskiego.

Centrum Badań i Edukacji Statystycznej GUS (2015). Badanie pilotażowe zachowań komunikacyjnych ludności w Polsce, etap III raport końcowy, Jachranka.

Engelhardt, J. (2007). Transport kolejowy. In: B. Liberadzki, L. Mindur (eds.), Uwarunkowania rozwoju systemu transportowego Polski. Warszawa-Radom: Wydawnictwo Instytutu Technologii Eksploatacji - PIB.

Paprocki, W. (1996). Marketing usług kolejowych. Warszawa: Kolejowa Oficyna Wydawnicza.

Rosa, G. (2013). Konkurencja na rynku usług transportowych. Warszawa: C.H. Beck.

Tomanek, R. (2002). Konkurencyjność transportu miejskiego. Katowice: Prace Naukowe Akademii Ekonomicznej w Katowicach.

Sprawozdanie z funkcjonowania rynku transportu kolejowego w 2016 r. (2017). Retrieved from: https://utk.gov.pl/pl/aktualnosci/ 13293,Sprawozdanie-z-funkcjonowania-rynku-transportu-kolejowego-w-2016-r.html.

Wykorzystanie i potencjał kolejowych przewozów pasażerskich w Polsce (2017). Warszawa: Urząd Transportu Kolejowego.

Wyszomirski, O. (ed.) (1994). Rynek przewozów pasażerskich. Gdańsk: Wydawnictwo Uniwersytetu Gdańskiego.

Wyszomirski, O. (1998). Funkcjonowanie rynku komunikacji miejskiej. Gdańsk: Wydawnictwo Uniwersytetu Gdańskiego.

Cite this article aS: Rosa, G. (2018). Passenger preferences in rail transport. European Journal of Service Management, 4 (28/1), 273-280. DOI: 10.18276/ejsm.2018.28/1-34. 